\title{
Hodgkin's lymphoma of the thyroid: a clinicopathologic study of five cases and review of the literature
}

\author{
Sa A Wang ${ }^{1}$, Aliyah Rahemtullah ${ }^{1}$, William C Faquin ${ }^{1}$, Janet Roepke ${ }^{2}$, Nancy Lee Harris ${ }^{1}$ \\ and Robert P Hasserjian ${ }^{1}$ \\ ${ }^{1}$ Department of Pathology, Massachusetts General Hospital, Harvard Medical School, Boston, MA, USA and \\ ${ }^{2}$ East Central Indiana Pathologists, PC, Muncie, IN, USA
}

\begin{abstract}
Hodgkin's lymphoma rarely involves the thyroid gland. We report the clinical and pathologic features of five cases of Hodgkin's lymphoma that presented as thyroid lesions. All five patients were females, aged 29-59 years. Three patients had a history of chronic thyroiditis and hypothyroidism and two were euthyroid. One patient had a remote history of Hodgkin's lymphoma. Imaging studies showed a 'cold' nodule (three cases) or a diffusely enlarged thyroid gland, resembling goiter or fibrosclerosing thyroiditis (two cases). Thyroid fineneedle aspiration was performed before thyroidectomy in all cases; three of these cases contained some atypical cells, raising the possibility of Hodgkin's lymphoma. Histologically, all cases were classical Hodgkin's lymphoma, nodular sclerosis subtype. The four patients with primary thyroid lymphoma had Stage IIE disease. All patients were treated with surgical excision and chemotherapy, with or without radiation therapy, and were alive after 2 months to 7 years of follow-up. A review of the English literature between 1962 and 2005 revealed 16 cases of thyroid Hodgkin's lymphoma, with a female preponderance and generally favorable outcome similar to the cases in our series. Hodgkin's lymphoma of the thyroid is rare and can mimic a primary thyroid epithelial tumor or thyroiditis clinically. Histologic diagnosis may be difficult due to marked fibrosis. Hodgkin's lymphoma should be considered in the differential diagnosis of thyroid neoplasms.
\end{abstract}

Modern Pathology (2005) 18, 1577-1584. doi:10.1038/modpathol.3800501; published online 7 October 2005

Keywords: thyroid; Hodgkin's; lymphoma; nodular sclerosis; thyroiditis

Lymphomas comprise $<5 \%$ of thyroid malignancies. ${ }^{1-3}$ The majority of thyroid lymphomas are nonHodgkin's lymphomas of B-cell origin that arise in the setting of thyroiditis. ${ }^{2,4,5}$ Classical Hodgkin's lymphoma is predominantly a nodal-based disease characterized by the presence of Reed-Sternberg cells residing in a mixture of non-neoplastic reactive cells. On rare occasions, the first manifestation of Hodgkin's lymphoma may be a disorder of an extranodal site, such as the gastrointestinal tract, ${ }^{6-8}$ nasopharyngeal region, ${ }^{9,10}$ central nervous system, ${ }^{11}$ kidney ${ }^{12,13}$ or other sites. ${ }^{14-16}$ Only rare cases of Hodgkin's lymphoma presenting in the thyroid have been reported in the literature. ${ }^{17-25}$ Although it is controversial whether these cases represent primary thyroid Hodgkin's lymphoma or secondary thyroid

Correspondence: Dr RP Hasserjian, MD, Department of Pathology, Massachusetts General Hospital, 55 Fruit Street, Boston, MA 02114, USA.

E-mail: rhasserjian@partners.org

Received 22 June 2005; revised and accepted 31 August 2005; published online 7 October 2005 involvement, the rarity of thyroid Hodgkin's lymphoma may lead to it being missed or not being considered in the differential diagnosis of a thyroid mass. Hodgkin's lymphoma presenting in the thyroid can mimic primary thyroid carcinoma or thyroiditis, producing diagnostic dilemmas.

Here, we report five cases of Hodgkin's lymphoma manifesting as a primary disorder of the thyroid gland. We also reviewed cases of thyroid Hodgkin's lymphoma reported in the English literature since 1962 in order to further characterize its clinicopathologic features.

\section{Materials and methods}

Source Materials

We searched the surgical pathology archives and consultation files of the Massachusetts General Hospital for all cases coded as 'Hodgkin's lymphoma' or 'Hodgkin's disease' in thyroidectomy specimens between 1990 and 2005. Five cases were retrieved. Formalin-fixed, paraffin-embedded tissues 
were available in all cases. Prior fine-needle aspiration (FNA) specimens were available for review in three cases, and cytology reports from FNAs were available in all five cases. Clinical follow-up was obtained for all cases.

\section{Cytologic, Histologic and Immunohistochemical Analysis}

The FNA specimens included direct smears and aspirates processed using the thin-layer preparation (thin-prep) method and stained with a modified Papanicolaou stain. In some cases, formalin-fixed paraffin-embedded and hematoxylin and eosin (H\&E)-stained cell-block sections were also available.

Thyroid surgical specimens were evaluated on formalin-fixed, paraffin-embedded and H\&E-stained sections. For immunohistochemistry, 2- $\mu \mathrm{m}$-thick paraffin sections of formalin-fixed tissue were deparaffinized and rehydrated, using standard protocols. Immunohistochemical studies were performed with monoclonal mouse anti-human CD20, CD3, CD30, CD15, ALK-1, CD21, cytokeratins AE1/AE3/Cam5.2, and Pax5 antibodies followed by avidin-biotin peroxidase complex using a peroxidase-labeled detection system and an automated immunostainer with antigen retrieval (Ventana Medical Systems, Tucson, AZ, USA). Sections were counterstained with hematoxylin. Histology and immunohistochemistry from all cases were reviewed by at least two of the authors to confirm the diagnosis.

In situ hybridization for EBV-encoded RNA was performed using HX automatic System Benchmark
(Ventana Medical Systems, Tuscon, AZ, USA) as per the manufacturer's instructions, with the probe for EBER (INFORM EBER probe, Ventana Medical Systems). Signals were detected using Alkaline Phosphatase Enhanced Detection Kit (Ventana Medical Systems).

\section{Results}

\section{Clinical Features}

All five patients were women aged 29-59 years. Three had a history of hypothyroidism for at least 1 year and one had a remote history of neck and mediastinal Stage IIA nodular sclerosis Hodgkin's lymphoma 14 years previously, treated with radiation therapy alone. The presentation, clinical features and follow-up of the five patients are shown in Table 1.

\section{Cytologic Findings}

The FNA specimens were of variable cellularity. In case 1, the FNA revealed large atypical cells in a background of mixed inflammatory cells, highly suspicious for Hodgkin's lymphoma (Figure 1a). In cases 2 and 3 , the aspirates were comprised predominantly of small lymphocytes with variable numbers of bland thyroid follicular cells, interpreted as consistent with chronic lymphocytic thyroiditis. In case 4, a total of three FNAs were performed over a period of 4 months: the initial two were nondiagnostic, while the third revealed scattered large atypical cells (including binucleate

Table 1 Clinicopathologic features of five patients with thyroid Hodgkin's lymphoma

\begin{tabular}{|c|c|c|c|c|c|c|}
\hline Case no. & $\begin{array}{l}\text { Age }(y r) / \\
\text { sex }\end{array}$ & Presenting symptoms & Thyroid function & Imaging & Stage & Treatment/outcome \\
\hline 1 & $42 / \mathrm{F}$ & Hoarseness and stridor & Hypothyroid for $1 \mathrm{yr}$ & $\begin{array}{l}\text { Isthmus and left lobe } \\
\text { enlargement, } \\
\text { mimicking goiter }\end{array}$ & IIE & $\begin{array}{l}\text { Partial thyroidectomy } \\
\text { followed by six cycles of } \\
\text { ABVD. Disease free for } \\
7 \mathrm{yr}\end{array}$ \\
\hline 2 & $50 / \mathrm{F}$ & $\begin{array}{l}\text { Rapidly growing neck } \\
\text { mass }\end{array}$ & Hypothyroid for $1 \mathrm{yr}$ & $\begin{array}{l}\text { Enlarged thyroid with } \\
\text { a } 3.5 \mathrm{~cm} \text { nodule in } \\
\text { isthmus }\end{array}$ & IIE & $\begin{array}{l}\text { Partial thyroidectomy } \\
\text { followed by six cycles of } \\
\text { ABVD. Disease free for } \\
3.5 \mathrm{yr}\end{array}$ \\
\hline 3 & $59 / \mathrm{F}$ & Dysphagia & Hypothyroid for $1 \mathrm{yr}$ & $\begin{array}{l}\text { Sclerotic thyroid with } \\
\text { ill-defined mass in } \\
\text { right lobe }\end{array}$ & IIE & $\begin{array}{l}\text { Complete thyroidectomy. } \\
\text { Complete response to two } \\
\text { cycles of ABVD at last } \\
\text { follow-up }\end{array}$ \\
\hline 4 & $29 / F$ & Dysphagia & Euthyroid & $\begin{array}{l}3.8 \mathrm{~cm} \text { left lobe mass } \\
\text { extending to superior } \\
\text { mediastinum }\end{array}$ & IIE & $\begin{array}{l}\text { No surgery to thyroid. } \\
\text { Complete response to two } \\
\text { cycles of AVG at last FU }\end{array}$ \\
\hline 5 & $46 / \mathrm{F}$ & $\begin{array}{l}\text { Painless thyroid nodule; } \\
\text { history of HL } 14 \text { yr ago }\end{array}$ & Euthyroid & $\begin{array}{l}1.6 \mathrm{~cm} \text { nodule in } \\
\text { isthmus, mimicking } \\
\text { adenoma }\end{array}$ & IE & $\begin{array}{l}\text { Complete thyroidectomy. } \\
\text { Recurred } 1 \text { yr later in } \\
\text { cervical LN. Treated with } \\
\text { ABVD, disease free at } 15 \\
\text { mo FU }\end{array}$ \\
\hline
\end{tabular}

$\mathrm{HL}=$ Hodgkin's lymphoma; $\mathrm{yr}=$ year; $\mathrm{mo}=$ month $\mathrm{ABVD}=$ doxorubicin, bleomycin, vinblastine and dacarbazine; AVG = adriamycin, vinblastine and gemcitabine; $\mathrm{FU}=$ follow-up; $\mathrm{LN}=$ lymph node. 

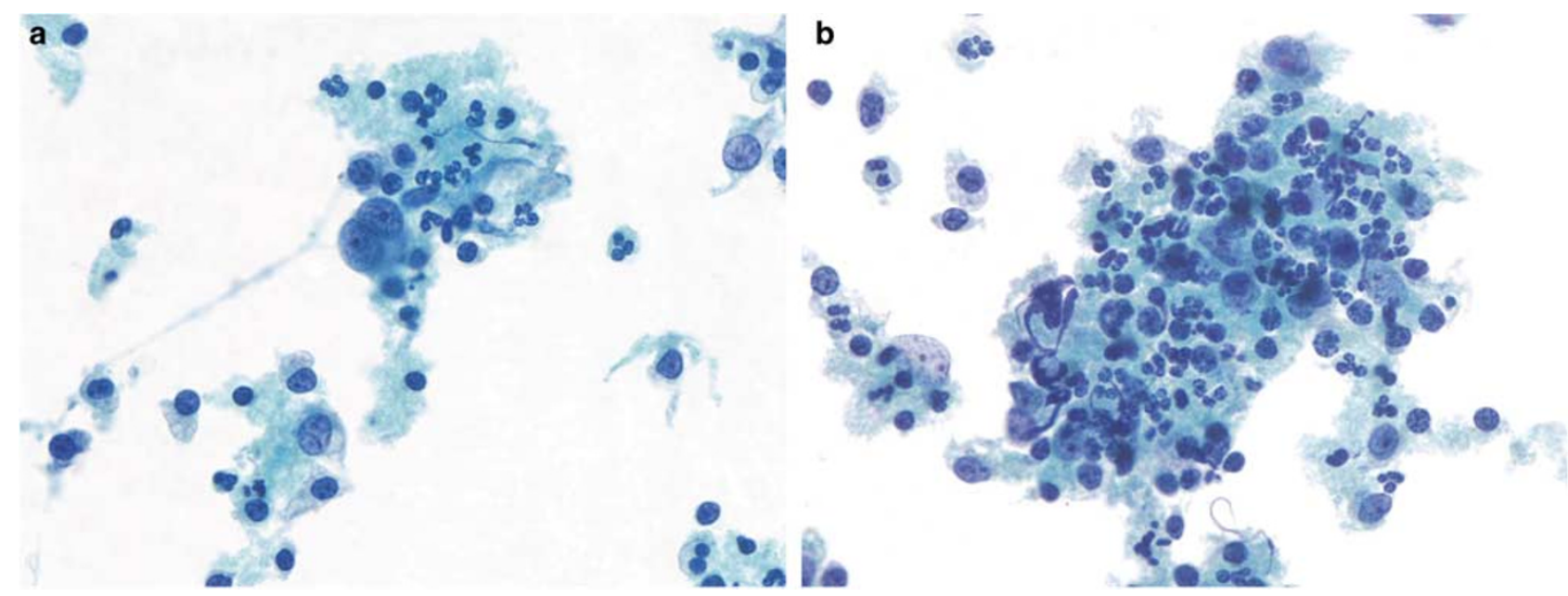

Figure 1 Fine-needle aspiration cytology of thyroid Hodgkin's lymphoma cases. (a) Case 1 showed occasional Reed-Sternberg cells in a background of mixed inflammatory cells (Papanicolaou stain, original magnification $\times 400$ ). (b) Case 4 showed clusters of large atypical mononuclear cells (Papanicolaou stain, original magnification $\times 400$ ).

forms) in a background of abundant lymphocytes and histiocytes (Figure 1b). The possibility of anaplastic thyroid carcinoma was raised. Immunocytochemical stains on direct smears, limited due to the paucity of material, showed that the malignant cells were negative for cytokeratins AE1/AE3/ Cam5.2 and for ALK-1; some of the large cells appeared to be positive for leukocyte common antigen (CD45). Both non-Hodgkin's and Hodgkin's lymphoma were included in the differential diagnosis. In case 5, the first FNA revealed predominantly follicular cells in macrofollicular groups and many small lymphocytes and was interpreted as a benign follicular lesion in a background of chronic thyroiditis. The FNA was repeated 1 month later and identified occasional large atypical cells in a background of macrofollicular epithelium and chronic thyroiditis, raising the possibility of recurrent Hodgkin's lymphoma.

\section{Gross and Microscopic Findings}

Grossly, the thyroid lobes or nodules were very firm, with variable sclerosis. Histologically, cases 1, 2, 3 and 5 showed prominent fibrosis, suggestive of the fibrosclerosing variant of Hashimoto's thyroiditis. Some features overlapped with those seen in Riedel's thyroiditis (Figure 2a); however, the fibroblastic proportion was more prominent and extrathyroid extension was much less pronounced. Scattered large atypical cells were embedded within the fibrotic stroma (Figure 2a, inset) admixed with variable numbers of eosinophils, with focal nodular cellular areas. These cellular areas contained a mixed population of lymphocytes, histiocytes, plasma cells, variable numbers of eosinophils and large atypical mononuclear and multinucleated cells consistent with Reed-Sternberg cells and variants. In all cases, the Reed-Sternberg cells were CD30 and CD15 positive and were CD20 negative, confirming the diagnosis of classical Hodgkin's lymphoma in the context of the histologic findings. All five cases were of the nodular sclerosis subtype. In case 4, thyroid tissue was not available for histologic examination and the diagnosis of classical Hodgkin's lymphoma, nodular sclerosis subtype, was made on a subsequent cervical lymph node biopsy. All cases were negative for EBV-encoded RNA by in situ hybridization. Reactive follicular atypia was present in all cases (Figure 2b).

\section{Thyroiditis}

Case 3 showed typical changes of Hashimoto's thyroiditis (Figure 2c and d) and case 1 showed focal changes of lymphocytic thyroiditis in areas uninvolved by Hodgkin's lymphoma.

\section{Discussion}

We report five cases of Hodgkin's lymphoma manifesting as a primary thyroid disorder. We reviewed the English literature between 1962 and 2005 for cases of primary thyroid Hodgkin's lymphoma. In all, 16 cases with convincing evidence of Hodgkin's lymphoma (an image illustrating typical histologic features, a convincing microscopic description, report of a lymph node biopsy showing classical Hodgkin's lymphoma and/or diagnostic immunohistochemistry) were found (Table 2). There were four males and 12 females aged 18 to 64 years. The female predominance observed in our cases and those reported in the literature is similar to that observed in primary non-Hodgkin's lymphoma of 

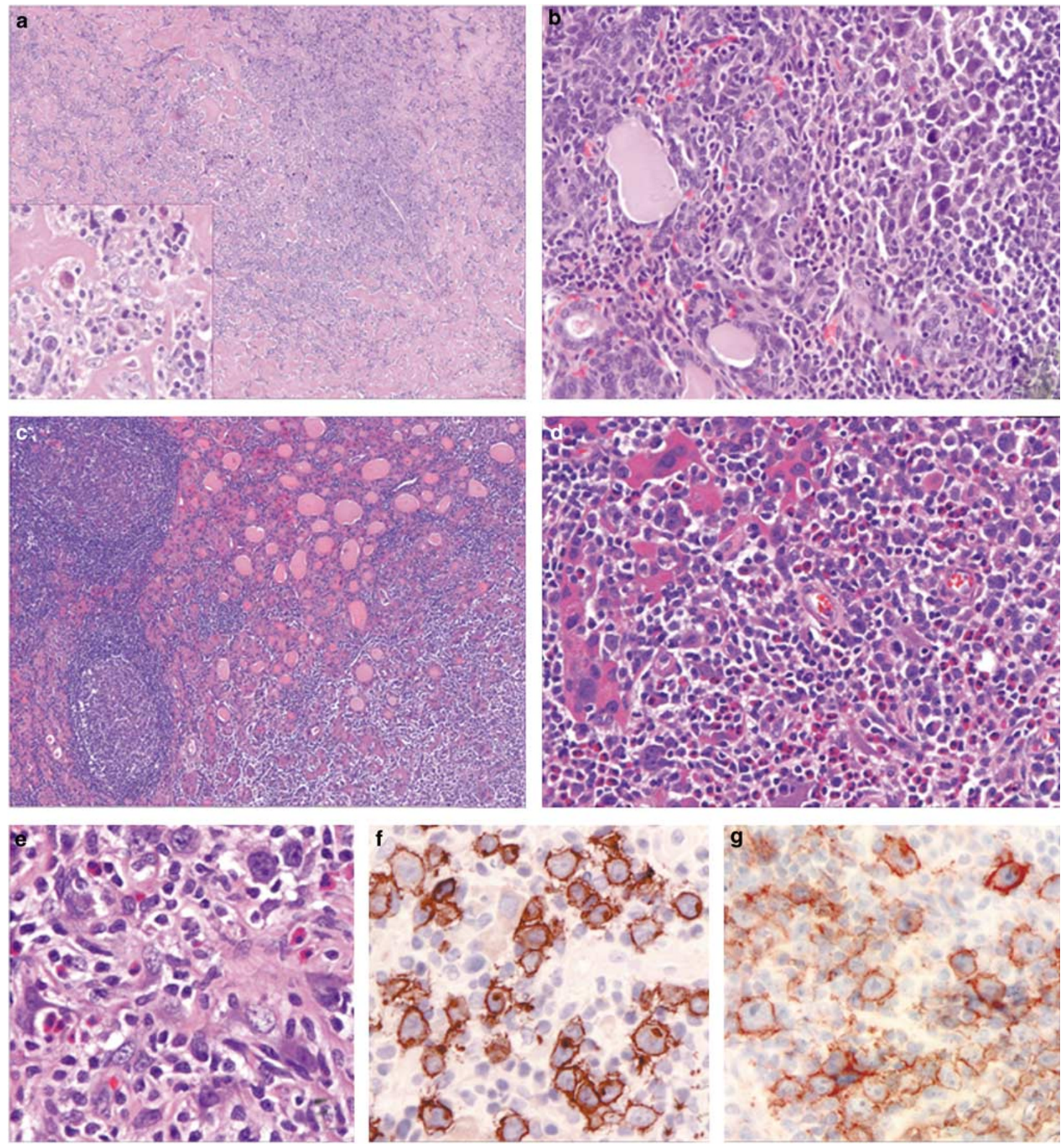

Figure 2 Histologic findings in thyroid Hodgkin's lymphoma. (a) Marked fibrosis and sclerosis with scattered Reed-Sternberg cells (inset) embedded in a sclerotic stroma (H\&E, original magnification $\times 50$, inset $\times 400)$. (b) Reactive epithelial atypia was present adjacent to Reed-Sternberg cells $(H \& E$, original magnification $\times 200)$. (c) Case 3 showed a background of Hashimoto's thyroiditis $(H \& E$, original magnification $\times 50$ ). (d) On higher magnification, Hurthle cells were admixed with Reed-Sternberg cells (H\&E, original magnification $\times 200)$. The latter cells $(\mathbf{e})(\mathrm{H} \& \mathrm{E}$, original magnification $\times 400)$ were positive for CD30 (f) and CD15 (g) (immunoperoxidase, original magnification $\times 400$ ).

the thyroid. ${ }^{26}$ However, thyroid Hodgkin's lymphoma patients tended to present at a younger age (median age 42 years for our cases combined with the reported cases) than thyroid non-Hodgkin's lymphoma patients, who tend to present between the ages of 50 and 80 years with a peak incidence in the sixth decade. ${ }^{26,27}$

Among our series and the cases reported in the literature, patients with Hodgkin's lymphoma commonly presented with a rapidly enlarging thyroid 
Table 2 Clinicopathologic features of previously reported cases of thyroid Hodgkin's lymphoma

\begin{tabular}{|c|c|c|c|c|c|c|c|c|}
\hline \multirow[t]{2}{*}{ Author } & \multirow{2}{*}{$\begin{array}{l}\text { Age }(y r) / \\
\text { sex }\end{array}$} & \multirow[t]{2}{*}{ Presenting symptoms } & \multirow{2}{*}{$\begin{array}{l}\text { Imaging/intraoperative } \\
\text { findings }\end{array}$} & \multicolumn{3}{|c|}{ Pathologic findings } & \multirow[t]{2}{*}{ Stage } & \multirow[t]{2}{*}{ Treatment/outcome } \\
\hline & & & & Evidence of $H L$ & $\begin{array}{l}\text { HL } \\
\text { subtype }\end{array}$ & Uninvolved thyroid & & \\
\hline Rupp et $a l^{37}$ & $64 / \mathrm{M}$ & $\begin{array}{l}\text { Neck pain, dysphagia and B } \\
\text { symptoms }\end{array}$ & Diffuse firmly enlarged thyroid & \multirow{2}{*}{$\begin{array}{l}\text { Image, } \\
\text { description, LN } \\
\text { biopsy } \\
\text { Image, } \\
\text { description }\end{array}$} & $\begin{array}{l}\text { Not } \\
\text { reported }\end{array}$ & $\begin{array}{l}\text { Lymphocytic } \\
\text { thyroiditis }\end{array}$ & IIE & Unknown \\
\hline Roberts et $a l^{38}$ & $61 / \mathrm{M}$ & Painful enlarging neck mass & $\begin{array}{l}\text { Firm tumor mass extending } \\
\text { into mediastinum and } \\
\text { invading trachea and carotid } \\
\text { sheath }\end{array}$ & & NS & $\begin{array}{l}\text { Hashimoto's thyroiditis } \\
\text { (12 yr previously) }\end{array}$ & IIE & $\begin{array}{l}\text { Subtotal neck mass } \\
\text { resection }\end{array}$ \\
\hline Gibson et $a l^{39}$ & $59 / F$ & $\begin{array}{l}6 \text { yr history of painless } \\
\text { progressive neck enlargement }\end{array}$ & $\begin{array}{l}\text { Soft-tissue swelling with } \\
\text { tracheal deviation }\end{array}$ & \multirow{2}{*}{$\begin{array}{l}\text { Image, } \\
\text { description, LN } \\
\text { biopsy } \\
\text { Image, } \\
\text { description }\end{array}$} & NS & $\begin{array}{l}\text { Lymphocytic } \\
\text { thyroiditis }\end{array}$ & IIE & $\begin{array}{l}\text { Thyroidectomy then XRT, } \\
\text { NED at } 6 \text { mo }\end{array}$ \\
\hline De Baets et $a l^{21}$ & $57 / F$ & $\begin{array}{l}6 \mathrm{yr} \text { history of goiter, with } \\
\text { rapid painful enlargement of } \\
\text { thyroid }\end{array}$ & Soft-tissue swelling & & NS & Not described & $\mathrm{IE}$ & $\begin{array}{l}\text { Subtotal thyroidectomy. No } \\
\text { other therapy, NED at } 6 \text { yr }\end{array}$ \\
\hline Feigin et $a l^{40}$ & $64 / \mathrm{F}$ & $\begin{array}{l}2 \text { yr history of small thyroid } \\
\text { nodule and hypothyroidism. } \\
\text { Hoarseness and weight loss }\end{array}$ & $\begin{array}{l}\text { No mediastinal } \\
\text { lymphadenopathy or lung } \\
\text { disease }\end{array}$ & $\begin{array}{l}\text { Image, } \\
\text { description }\end{array}$ & NS & $\begin{array}{l}\text { Lymphocytic } \\
\text { thyroiditis }\end{array}$ & IIE & $\begin{array}{l}\text { Thyroid lobectomy, chemo } \\
\text { and XRT, NED at } 3 \text { yr }\end{array}$ \\
\hline Kugler et $a l^{41}$ & $27 / F$ & $\begin{array}{l}\text { Slow thyroid enlargement over } \\
1 \text { yr. Stridor, hoarseness and } \\
\text { dysphagia over } 3 \text { wk }\end{array}$ & $\begin{array}{l}\text { Thyroid mass contiguous with } \\
\text { mediastinal mass. Tracheal } \\
\text { deviation and narrowing }\end{array}$ & $\begin{array}{l}\text { Image, } \\
\text { description }\end{array}$ & NS & Not described & IIIE & $\begin{array}{l}\text { Subtotal resection and } \\
\text { chemo, no FU }\end{array}$ \\
\hline Mate et $a l^{42}$ & $60 / \mathrm{F}$ & $\begin{array}{l}1 \text { yr history of hypothyroidism, } \\
\text { then dysphagia and } \\
\text { hoarseness }\end{array}$ & $\begin{array}{l}\text { Mass involving cricoid } \\
\text { cartilage, esophagus and } \\
\text { mediastinum }\end{array}$ & LN biopsy & MC & No described & IIE & $\begin{array}{l}\text { XRT alone, recurred in lung } \\
\text { after } 6 \text { mo, treated with } \\
\text { chemo }\end{array}$ \\
\hline Mate et $a l^{42}$ & $25 / \mathrm{F}$ & Enlarging goiter and dysphagia & $\begin{array}{l}\text { Thyroid mass compressing } \\
\text { trachea and displacing } \\
\text { esophagus }\end{array}$ & LN biopsy & NS & Not described & IIE & $\begin{array}{l}\text { XRT alone, recurred } 2 \mathrm{yr} \\
\text { later in abdomen, treated } \\
\text { with chemo, NED at } 7 \mathrm{yr}\end{array}$ \\
\hline Smith et $a l^{22}$ & $19 / \mathrm{F}$ & $\begin{array}{l}5 \mathrm{yr} \text { history of goiter, then } \\
\text { dysphagia, dyspnea and } \\
\text { rapidly enlarging thyroid }\end{array}$ & $\begin{array}{l}\text { Firm thyroid adherent to } \\
\text { trachea and esophagus }\end{array}$ & Description & NS & Not described & IIE & $\begin{array}{l}\text { With chemo, NED at } 7 \text { yr } \\
\text { Unknown }\end{array}$ \\
\hline Granados et $a l^{29}$ & $36 / \mathrm{F}$ & $\begin{array}{l}1 \text { yr history of goiter and } \\
\text { hypothyroidism. Increase in } \\
\text { size and firmness despite } \\
\text { thyroid hormone therapy }\end{array}$ & $\begin{array}{l}\text { Bulky mediastinal mass } \\
\text { infiltrating thyroid with } \\
\text { tracheal narrowing }\end{array}$ & RS cells CD15+ & NS & Not described & IIE & XRT alone, NED at $1 \mathrm{yr}$ \\
\hline Vailati et $a l^{23}$ & $29 / \mathrm{F}$ & $\begin{array}{l}2 \text { mo history of thyroid } \\
\text { enlargement, stridor, low- } \\
\text { grade fever, fatigue and } \\
\text { pruritus }\end{array}$ & $\begin{array}{l}\text { Homogeneous mass involving } \\
\text { isthmus and left lobe, with } \\
\text { tracheal displacement }\end{array}$ & $\begin{array}{l}\text { Image, } \\
\text { description }\end{array}$ & NS & Not described & $\mathrm{IE}$ & $\begin{array}{l}\text { Subtotal thyroidectomy, } \\
\text { and XRT, NED at } 2 \text { yrs }\end{array}$ \\
\hline Jayaram $^{43}$ & $53 / \mathrm{F}$ & $\begin{array}{l}\text { Neck swelling for } 2 \text { mo, then } \\
\text { cervical lymphadenopathy } \\
\text { and hepatosplenomegaly }\end{array}$ & $\begin{array}{l}6 \mathrm{~cm} \text { firm nodule in left lobe, } \\
\text { no mediastinal or hilar } \\
\text { lymphadenopathy }\end{array}$ & $\begin{array}{l}\text { Description, LN } \\
\text { biopsy }\end{array}$ & $\begin{array}{l}\text { Not } \\
\text { reported }\end{array}$ & Not described & IV & $\begin{array}{l}\text { Thyroid lobectomy, lost to } \\
\text { FU }\end{array}$ \\
\hline Hardoff et $a l^{30}$ & $20 / \mathrm{F}$ & $\begin{array}{l}1 \text { yr history of solitary painless } \\
\text { thyroid nodule, then } \\
\text { developed cervical }\end{array}$ & $\begin{array}{l}\text { Cervical, axillary and } \\
\text { mediastinal lymphadenopathy }\end{array}$ & $\begin{array}{l}\text { Description, LN } \\
\text { biopsy }\end{array}$ & NS & Not described & IIE & $\begin{array}{l}\text { Chemo and XRT, NED at } \\
1 \mathrm{yr}\end{array}$ \\
\hline Hardoff et $a l^{30}$ & $18 / \mathrm{F}$ & $\begin{array}{l}\text { lymphadenopathy } \\
\text { Painless throat fullness, } \\
\text { dysphagia, fever }\end{array}$ & $\begin{array}{l}\text { Solitary left thyroid nodule, } \\
\text { mediastinal and cervical } \\
\text { lymphadenopathy }\end{array}$ & $\begin{array}{l}\text { RS cells CD30+, } \\
\text { CD15+ }\end{array}$ & NS & Not described & IIE & $\begin{array}{l}\text { Chemo and XRT, NED at } \\
18 \mathrm{mo}\end{array}$ \\
\hline $\begin{array}{l}\text { Luboshitzky et } \\
a^{31}\end{array}$ & $19 / F$ & $\begin{array}{l}\text { Single nodule in left lobe of } \\
\text { thyroid }\end{array}$ & $\begin{array}{l}5 \mathrm{~cm} \text { mediastinal mass and an } \\
\text { enlarged cervical lymph node }\end{array}$ & $\begin{array}{l}\text { RS cells CD30+, } \\
\text { CD15+ }\end{array}$ & NS & Not described & IIE & $\mathrm{NED}$ at $2 \mathrm{yr}$ \\
\hline Nakamura et $a l^{44}$ & $18 / \mathrm{M}$ & $\begin{array}{l}\text { Progressively enlarging neck } \\
\text { mass and dyspnea }\end{array}$ & $\begin{array}{l}\text { Large mass involving entire } \\
\text { thyroid, extending into } \\
\text { mediastinum }\end{array}$ & $\begin{array}{l}\text { RS cells CD30+, } \\
\text { CD15+ }\end{array}$ & NS & Not described & IIE & XRT alone, NED at $4 \mathrm{yr}$ \\
\hline
\end{tabular}


gland or a thyroid mass, similar to the presentation of non-Hodgkin's lymphoma of the thyroid. ${ }^{5}$ The mass may cause symptoms related to compression or infiltration of the surrounding neck organs. Symptoms reflecting airway or esophageal obstruction occurred in $3 / 5$ patients in our series and in 9/16 of the previously reported cases. On physical examination, the thyroid mass was commonly described as being hard upon palpation. Both bilateral and unilateral involvement were reported. Imaging studies revealed either a diffusely enlarged thyroid or 'cold' nodules, mimicking thyroiditis or a primary thyroid follicular lesion (Tables 1 and 2).

Open surgical biopsy has traditionally been required to diagnose thyroid lymphoma. When combined with modern immunophenotypic analysis, FNA has greatly increased our ability to diagnose non-Hodgkin's lymphoma, ${ }^{28}$ thus surgical intervention is often unnecessary for the initial diagnosis of thyroid non-Hodgkin's lymphoma. However, experience with FNA in the diagnosis of Hodgkin's lymphoma is limited because of its rarity in the thyroid. Several case reports have suggested that FNA might have some value in diagnosis of Hodgkin's lymphoma of the thyroid ${ }^{25,29-31}$ and in the six cases from our literature review which provided FNA results, four were consistent with Hodgkin's lymphoma, one was suspicious for Hodgkin's lymphoma and one was diagnosed as lymphocytic thyroiditis. However, in our series, although three of the five cases eventually showed some large atypical cells on FNA, two of these three cases required more than one attempt to obtain diagnostic material. Another two cases were considered consistent with chronic thyroiditis and the diagnosis of lymphoma was not suspected. This relatively low accuracy of FNA in the diagnosis of thyroid Hodgkin's lymphoma may be largely due to the scarcity of diagnostic Reed-Sternberg cells in aspirates as well as the marked associated fibrosis and sclerosis resulting in hypocellular or nondiagnostic samples. In addition, the rarity and unusual presentation of thyroid Hodgkin's lymphoma may lead to misinterpretation of the rare large atypical cells as reactive rather than malignant. Although examination of biopsy material will be usually necessary to confirm a diagnosis of Hodgkin's lymphoma, when adequate material is obtained, FNA may be valuable in raising the possibility of Hodgkin's lymphoma and thereby helping to guide subsequent clinical intervention.

All cases in our series and the reported cases were classical Hodgkin's lymphoma and all of our cases and 13/14 of the reported cases that were subclassified were of the nodular sclerosis subtype. This is consistent with the well-recognized tendency for this subtype to occur in the mediastinum and head and neck region. ${ }^{32}$ In many cases, the associated fibrosis and sclerosis were more pronounced within the thyroid gland in comparison to the adjacent nodal areas, mimicking the fibrosclerosing variant of
Hashimoto's thyroiditis or in some cases Reidel's thyroiditis, and requiring careful histologic examination and immunohistochemical analysis to make the diagnosis of Hodgkin's lymphoma.

In thyroid Hodgkin's lymphoma, including the reported cases and the cases in our series, the majority of patients presented with Stage IIE disease, with mediastinal and/or regional lymph node involvement. The question thus arises as to whether Hodgkin's lymphoma of the thyroid gland represents a primary event or reflects secondary involvement by nodal or thymic Hodgkin's lymphoma. The association between non-Hodgkin's lymphoma and a pre-existing lymphocytic or Hashimoto's thyroiditis has been well-recognized. ${ }^{5,33}$ The thyroid gland contains no native lymphoid tissue; intrathyroidal lymphoid tissue can develop in various pathological conditions, but most commonly occurs in the setting of autoimmune thyroiditis. This acquired lymphoid tissue bears a close resemblance to mucosa-associated lymphoid tissue and can evolve to an extranodal marginal zone B-cell lymphoma. ${ }^{34}$ The development of extranodal marginal zone B-cell lymphoma in the thyroid gland is often characterized by an indolent course, but transformation to an aggressive lymphoma can also occur. ${ }^{34,35}$ In contrast, any association between Hodgkin's lymphoma and underlying thyroiditis has been difficult to document because of the small number of cases. Of the 21 patients in Tables 1 and 2 , at least seven had a well-documented clinical history of chronic thyroiditis several months to years prior to the presentation of Hodgkin's lymphoma. In three of these seven cases and in at least three additional cases occurring in euthyroid patients, lymphocytic or Hashimoto's thyroiditis were demonstrated histologically in areas uninvolved with Hodgkin's lymphoma. Interestingly, in contrast to systemic Hodgkin's lymphoma, which has an equal male to female ratio, thyroid Hodgkin's lymphoma shows a striking female preponderance, mirroring the female predominance seen in autoimmune thyroiditis as well as other thyroid disorders. While the lymphocytic thyroid infiltrates may represent a reactive process secondary to the Hodgkin's lymphoma, it appears that at least a subset of thyroid Hodgkin's lymphoma are associated with antecedent autoimmune thyroiditis.

Most of the thyroid Hodgkin's lymphoma patients presented with low-stage disease, responded to chemotherapy with or without radiation therapy and had a favorable clinical outcome. Surgical intervention is rarely required in the treatment of nodal Hodgkin's lymphoma. However, in thyroid Hodgkin's lymphoma, some patients presented with symptoms that compromised their airway or caused severe pain, requiring surgical therapy to palliate their symptoms. Surgical intervention did not appear to be associated with adverse outcome in thyroid Hodgkin's lymphoma patients, similar to thyroid non-Hodgkin's lymphoma patients. ${ }^{36}$ 


\section{References}

1 Doria R, Jekel JF, Cooper DL. Thyroid lymphoma. The case for combined modality therapy. Cancer 1994;73: 200-206.

2 Compagno J, Oertel JE. Malignant lymphoma and other lymphoproliferative disorders of the thyroid gland. A clinicopathologic study of 245 cases. Am J Clin Pathol 1980;74:1-11.

3 Samaan NA, Ordonez NG. Uncommon types of thyroid cancer. Endocrinol Metab Clin N Am 1990; 19:637-648.

4 Ansell SM, Grant CS, Habermann TM. Primary thyroid lymphoma. Semin Oncol 1999;26:316-323.

5 Derringer GA, Thompson LD, Frommelt RA, et al. Malignant lymphoma of the thyroid gland: a clinicopathologic study of 108 cases. Am J Surg Pathol 2000; 24:623-639.

6 Coppens E, El Nakadi I, Nagy N, et al. Primary Hodgkin's lymphoma of the esophagus. Am J Roentgenol 2003;180:1335-1337.

7 Thomas DB, Huston BM, Lamm KR, et al. Primary Hodgkin's disease of the sigmoid colon: a case report and review of the literature. Arch Pathol Lab Med 1997;121:528-532.

8 Kumar S, Fend F, Quintanilla-Martinez L, et al. Epstein-Barr virus-positive primary gastrointestinal Hodgkin's disease: association with inflammatory bowel disease and immunosuppression. Am J Surg Pathol 2000;24:66-73.

9 Tanaka J, Yoshida K, Suzuki M, et al. Hodgkin's disease of the maxillary gingival. A case report. Int J Oral Maxillofac Surg 1992;21:45-46.

10 Malis DD, Moffat D, Garry GW. Isolated nasopharyngeal Hodgkin's disease presenting as nasal obstruction. Int J Clin Pract 1998;52:343-346.

11 Herrlinger U, Klingel K, Meyermann R, et al. Central nervous system Hodgkin's lymphoma without systemic manifestation: case report and review of the literature. Acta Neuropathol 2000;99:709-714.

12 Sharma SK, Hemal AK, Goswami AK, et al. Primary renal Hodgkin's lymphoma: case report. Urol Int 1989;44:313-315.

13 Oldhafer KJ, Bunzendahl H, Frei U, et al. Primary Hodgkin's lymphoma: an unusual cause of graft dysfunction after kidney transplantation. Am J Med 1989;87:218-220.

14 Poyrazoglu E, Cincik H, Gungor A, et al. Primary Hodgkin's lymphoma of the parotid gland: a case report. Kulak Burun Bogaz Ihtis Derg 2003;11: 21-24.

15 Perin T, Canzonieri V, Gloghini A, et al. Primary Hodgkin's disease of the vagina. Leukemia Lymphoma 2000;37:451-455.

16 Ozdermirli M, Mankin HJ, Aisenberg AC, et al. Hodgkin's disease presenting as a solitary bone tumor. A report of four cases and review of the literature. Cancer 1996;77:79-88.

17 Abel WG, Finnerty J. Primary Hodgkin's disease of thyroid. NY State J Med 1969;69:314-315.

18 Langenhuijsen MM, Eibergen R, Halie MR. Primary extranodal Hodgkin's disease; report of five cases and survey of the literature. Neth J Med 1976;19: 224-233.

19 Bielicki F, Dolinski J, Kociatkiewicz P, et al. Primary Hodgkin's disease of the thyroid gland. Wiad Lek 1980;33:393-395.
20 Tuchong L, Hughes F, Harmer CL. Primary lymphoma of the thyroid: clinical features, prognostic factors, and results of treatment. Int J Radiat Oncol Biol Phys 1986;12:1813-1821.

21 De Baets M, Vanholder R, Eeckhaut $\mathrm{W}$, et al. Primary Hodgkin's disease of the thyroid. Report of a case demonstrated by immunoperoxidase-positive Reed-Sternberg cells. Acta Haematol 1981;65:54-59.

22 Smith P, Brown B, Gray SW, et al. Primary Hodgkin's disease of the thyroid gland. J Med Assoc Ga 1986;75:538-540.

23 Vailati A, Marena C, Aristia L, et al. Primary Hodgkin's disease of the thyroid: report of a case and a review of the literature. Haematologica 1991;76:69-71.

24 Brownlie BE, Fitzharris BM, Abdelaal AS, et al. Primary thyroid lymphoma: clinical features, treatment and outcome: a report of 8 cases. NZ Med J 1994;107:301-304.

25 Jamski J, Barczynski M, Konturek A. Hodgkin’s disease in the thyroid gland. Przeglad Lekarski 1998;55: 288-289.

26 Belal AA, Allam A, Kandil A, et al. Primary thyroid lymphoma: a retrospective analysis of prognostic factors and treatment outcome for localized intermediate and high grade lymphoma. Am J Clin Oncol 2001; 24:299-305.

27 Matsuzuka F, Miyauchi A, Katayama S, et al. Clinical aspects of primary thyroid lymphoma: diagnosis and treatment based on our experience of 119 cases. Thyroid 1993;3:93-99.

28 Cha C, Chen H, Westra WH, et al. Primary thyroid lymphoma: can the diagnosis be made solely by fine-needle aspiration? Ann Surg Oncol 2002;9: 298-302.

29 Granados R, Pinkus GS, West P, et al. Hodgkin's disease presenting as an enlarged thyroid gland. Report of a case diagnosed by fine needle aspiration. Acta Cytol 1991;35:439-442.

30 Hardoff R, Bar-Shalom R, Dharan M, et al. Hodgkin's disease presenting as a solitary thyroid nodule. Clin Nucl Med 1995;20:37-41.

31 Luboshitzky R, Dharan M, Nachtigal D, et al. Syncytial variant of nodular sclerosing Hodgkin's disease presenting as a thyroid nodule. A case report. Acta Cytol 1995;39:543-546.

32 Colby TV, Hoppe RT, Warnke RA. Hodgkin's disease: a clinicopathologic study of 659 cases. Cancer 1982;49: 1848-1858.

33 Yamauchi A, Tomita Y, Takakuwa T, et al. Polymerase chain reaction-based clonality analysis in thyroid lymphoma. Int J Mol Med 2002;10:113-117.

34 Pedersen RK, Pedersen NT. Primary non-Hodgkin's lymphoma of the thyroid gland: a population based study. Histopathology 1996;28:25-32.

35 Laing R, Hoskin P, Hudson B, Hudson G, et al. The significance of MALT histology in thyroid lymphoma: a review of patients from the BNLI and Royal Marsden Hospital. Clin Oncol 1994;6:300-304.

36 Sippel RS, Gauger PG, Angelos P. Palliative thyroidectomy for malignant lymphoma of the thyroid. Ann Surg Oncol 2002;9:907-911.

37 Rupp JJ, Moran JJ, Griffeth JR. Goiter as initial manifestation of Hodgkin's disease. Arch Intern Med 1962;110:386-388.

38 Roberts TW, Howard RG. Primary Hodgkin's disease of the thyroid: report of a case and review of the literature. Ann Surg 1963;157:625-632. 
39 Gibson JM, Prinn MG. Hodgkin's disease involving the thyroid gland. Br J Surg 1968;55:236238.

40 Feigin GA, Buss DH, Paschal B, et al. Hodgkin's disease manifested as a thyroid nodule. Hum Pathol 1982;13:774-776.

41 Kugler JW, Armitage JO, Dick FR. Hodgkin's disease presenting as a thyroid mass. Postgrad Med 1982;72: $243-245$.
42 Mate TP, Chen MG. Hodgkin's disease manifesting as Hashimoto's thyroiditis. Arch Intern Med 1984;144: 1473-1474.

43 Jayaram G. Hodgkin's disease beginning as a thyroid nodule [letter]. Acta Cytol 1993;37:256-257.

44 Nakamura S, Mizukami Y, Yokoyama K, et al. Thyroid tumor as initial presentation of Hodgkin's disease: a case report including an immunophenotypic characterization. Acta Haematol 1997;98:214-216. 